\title{
EFFECT OF DIFFERENT FUNGICIDE SEED TREATMENTS ON THE OCCURRENCE OF GRAM WILT
}

\author{
Wali Muhammad ${ }^{1}$, Ijaz Ahmad ${ }^{1}$, Hassan Tariq Bhatti ${ }^{1}$, Muhammad Irshad ${ }^{1}$, Umair Akhtar ${ }^{2}$ \\ ${ }^{1}$ Pest Warning and Quality Control of Pesticides, Agriculture Department, Government of Punjab, Pakistan. \\ ${ }^{2}$ Crop Reporting Service, Government of Punjab, Pakistan.
}

\section{ART I C L E I N F O}

\section{Article history}

Received: $13^{\text {th }}$ May, 2019

Revised: 29th July, 2019

Accepted: $28^{\text {th }}$ August, 2019

\section{Keywords}

Chickpea

Gram wilt

Seed treatment

Incidence

Cicer arietinum

\section{A B S T R A C T}

Chickpea (Cicer arietinum L.) is the world's third most important pulse crop. It belongs to the pea family with short and hairy pods containing usually two seeds. Chickpea is an important high protein crop of "Thal" area in Pakistan having major source of protein in animal feed and human diet especially for low income group, by supplementing their cereal diets. There was a study gap regarding field efficacy of different fungicides being used as seed treatment. To address this deficiency, efficacy of three different fungicides was studied in field against occurrence of gram wilt. The research trial was conducted at the farmer field during gram growing season of 2016-2017. Crop was sown on $20^{\text {th }}$ of October by adopting standard seed rate, row to row and plant to plant distance, fertilizer and irrigation plan. Observations were recorded on weekly basis from sowing to harvesting of crop and grain yield was also recorded. Results showed that Divind Star 036FS (difenconazole + cyproconazole) $@ 1 \mathrm{ml} / \mathrm{kg}$ of seed is best by minimum disease occurrence with mean of $7.18 \%$ compared with $39.26 \%$ in control. Although statistically similar results were obtained of all three fungicide treatments with efficacy order of Divind Star 036FS > Teranil 45 DP > Dynasty 125 FS. Divind Star 036FS also proved most effective for better yield followed by Teranil $45 \mathrm{DP}$ (bromothelanil) $5 \mathrm{~g} / \mathrm{kg}$ of seed with mean of 340.67 and 332.66 g per $\mathrm{m}^{2}$ respectively. Control plot showed minimum yield with mean of $193 \mathrm{~g} / \mathrm{m}^{2}$. Comparative study of percent germination of gram crop in field after seed treatment with three different fungicides showed that Dynasty 125 FS (ezoxystrobin + fludioxonil + mefenoxam) @ $3 \mathrm{ml} / \mathrm{kg}$ of seed was best with maximum mean germination of $78.33 \%$ over control.

Corresponding Author: Wali Muhammad

Email: walientomologist@gmail.com

(C) 2019 EScience Press. All rights reserved.

\section{INTRODUCTION}

Chickpea or Chana (Cicer arietinum) is also known as gram in Pakistan. It is an annual legume and belongs to the Fabaceae family while Faboideae is its subfamily. Chickpea is ranked as the third most popular pulse crop
(Dhar and Gurha, 1998). Chickpea is widely adopted and popular for preparing salads, falafel and chana masla except its basic use as pulse. Chickpea have basic dietary importance due to presence of protein, carbohydrates, 
minerals, vitamins and fibers in it. Globally, about 14.81 hectares are under cultivation of chickpea with annual production of 14.24 million tons (FAO, 2014). Pakistan is almost self-sufficient in chickpea production with a total chickpea producing area of one million hectares and production of 0.75 million tons annually. Major chickpea producing areas of Punjab province includes sandy areas (Thal region) of Layyah, Bhakkar, Mianwali, Faisalabad, Jhang, Chakwal and Khushab districts (Khan et al., 1991). There are many biotic and abiotic factors limiting the yield of chickpea in the world including insect pests and diseases. In Pakistan, production of chickpea per unit area is very low ( $10 \%$ of world) and decreasing year to year (Auckland and Van-der-Maesen, 1980).

Gram wilt is a widespread disease in the world and known as a major factor responsible for low productivity in Indian subcontinent. Fusarium oxysporum f.sp. cicero (Foc) was identified as the causal organism of wilt disease in gram and lentil crops (Ahmad, 2010; Haware, 1990; Jalali and Chand, 1992; Nene and Reddy, 1987). Gram wilt is also dependent on weather conditions of the area and can cause severe yield losses ranging from $10 \%$ to $40 \%$ (Bouslama, 1980; Trapero-Casas and JiménezDíaz, 1985). The whole crop may damage when environmental conditions are favoring the disease. However, late wilting is less damaging as compared with the wilting at early stages. The studies proved that spores of Foc can survive for six years in the soil in the absence of suitable host (Haware et al., 1996). Selection of resistant cultivar is the most feasible and economical method to control gram wilt in the field (Bakhsh et al., 2007). Steady resistance against gram wilt has been reported in eighty two genotypes of chickpea and these genotypes can be helpful for integrated disease management (Ayub et al., 2010).

Gram wilt is caused by soil borne and seed borne pathogen Fusarium oxysporum f.sp. ciceri (Foc) which is destructive to chickpea. Its control with chemicals and cultural practices is difficult. The disease can appear at any time in the field depending on the environmental conditions and susceptibility of sown gram cultivar between 25 days after sowing till maturity (Nene, 1985). The only cost effective and possible chemical control is seed dressing with fungicides (Pande et al., 2007; Pandey et al., 2018). Theses fungicides may help in suppression of disease causing pathogens and plant growth enhancement. Seed treatment of gram seed can delay the occurrence of said disease and reduce percent losses in yield. There are many fungicides claimed for the treatment of gram wilt, but farmers have no guidance regarding appropriate dose and application method of fungicide application. The objective of this study was to observe impacts of seed treatment on wilt occurrence in chickpea under field conditions. The present paper reports the efficacy and importance of fungicides used in seed dressing to check Fusarium wilt.

\section{MATERIAL AND METHODS}

A sick farmer field was selected in Chak No. 258 TDA, Tehsil Karor Lal Easan, District Layyah in 2016-2017 based on previous pest survey reports of the Pest Warning and Quality control of Pesticides, Punjab during the year 2015-16. A resistant variety, Punjab-2008 (Shafiq et al., 2011) was selected and purchased from the local market according to seed rate of $60 \mathrm{~kg} /$ hectare. Three different fungicides were selected from the running market and details are given in Table 1.

Table 1. Formulation, dose and generic names of fungicides used in the study.

\begin{tabular}{llll}
\hline Sr. No. & Treatment & Dose/kg of seed & Active Ingredients \\
\hline 1 & Dynasty 125 FS & $3 \mathrm{ml}$ & Ezoxystrobin + Fludioxonil + Mefenoxam \\
2 & Teranil 45 DP & $5 \mathrm{~g}$ & Bromothelanil \\
3 & Divind Star 036 FS & $1 \mathrm{ml}$ & Difenconazole + Cyproconazole \\
4 & Control & & Only water \\
\hline
\end{tabular}

All the three fungicides (for two kg of chickpea seeds) were mixed in two glasses of water and slowly poured on the seed kept on plastic sheets. These sheets were manually shaken by two persons to thoroughly mix the seed with fungicide solution. The treated chickpea seed was drilled on $20^{\text {th }}$ of October 2017 with manual seed drill in plots measuring $5 \times 5$ meter in randomized complete block design (RCBD) with four replications having row to row distance $45 \mathrm{~cm}$ (Berani et al., 2018). Basal fertilizer $\mathrm{N}$ : P: K (15-25-20) per hectare was applied at the time of sowing and no irrigation was applied and crop was raised on rainfed conditions. Other cultural practices like weeding and hoeing were also kept uniform for all the plots including control. No fungicide or insecticide was 
sprayed on the crop except used in seed treatment. Data was recorded one week after sowing regarding percent germination and that of wilting on fortnightly basis from 11-05-2017 to 24-04-2018 when crop was completely germinated after two weeks of sowing. Data regarding disease incidence was recorded from on meter square of each plot counting the total plant and disease affected plants. Percentage of disease incidence was calculated as per given formula:

Disease Incidence $(\%)=\frac{\text { Number of wilted plants }}{\text { Total number plants }} \times 100$ The data was arranged on Microsoft Excel sheets and analyzed using Statistix 8.1 software and means were compared among all the treatment using Duncan Multiple range test at $5 \%$ probability. The disease incidence was correlated with metrological parameters.

\section{RESULTS}

The data regarding correlation between disease incidence and different metrological parameters are given in Table 2 . These observations indicated that relative humidity, rainfall, maximum temperature and minimum temperature had important impacts on gram wilt disease in all treatments. Incidence of gram wilt showed a positive but non-significant correlation with maximum and minimum average temperature but positive and significant (0.69) correlation with rainfall. The negative but nonsignificant correlation was observed between gram wilt incidence and relative humidity for all treated and nontreated plots. Degree of correlation was variable among all the treatments and control.

Table 2. Correlation between meteorological parameters and wilt incidence.

\begin{tabular}{lcccc}
\hline \multicolumn{1}{c}{ Variable } & Dynasty 125 FS & Teranil 45 DP & Divind STAR 036FS & Control \\
\hline Maximum & 0.29 & 0.28 & 0.42 & 0.41 \\
Minimum & 0.39 & 0.35 & 0.48 & 0.49 \\
Relative Hhumidity & -0.43 & -0.29 & -0.49 & -0.53 \\
\multicolumn{1}{c}{ Rainfall (mm) } & $0.69^{*}$ & $0.64^{*}$ & $0.59^{*}$ & $0.61^{*}$ \\
\hline
\end{tabular}

Significant at 5\%

Seed treatment of all the three fungicides have shown positive results on germination of crop and yield $/ \mathrm{m}^{2}$ over control (Table 3). Similarly, gram wilt incidence was significantly reduced in all the treated plots as compared with control. As shown in Table 3, Dynasty 125 FS treated seed had highest germination rate $(78.33 \%)$ followed by Teranil 45 DP (72.50\%). Non-treated seeds have shown minimum percentage of germination of $55 \%$. Maximum disease incidence was recorded in control plot (39.26\%) which was significantly higher than all the three fungicide treatments.

The minimum wilt incidence (7.18\%) was noted in Divind Star 036FS seed treated plots followed by Teranil 45 DP (9.13\%). Dynasty 125 FS have significant results as compared with control but non-significant to other two fungicides. Sees treated with Divind Star 036FS have also increased yield significantly $\left(340\right.$ grams $\left./ \mathrm{m}^{2}\right)$ as compared with control (193 grams $/ \mathrm{m}^{2}$ ) only. Teranil 45 DP and Dynasty 125 FS showed statistically at par results to each other but significant to control (Table 3).

Table 3. Results of crop germination (\%), disease incidence (\%) and yield $/ \mathrm{m}^{2}$ (grams) in different plots having seed treatment of different fungicides.

\begin{tabular}{lccc}
\hline Treatment & Germination (\%) & Disease incidence (\%) & Yeild $/ \mathrm{m}^{2}(\mathrm{~g})$ \\
\hline Dynasty 125 FS & $78.33 \mathrm{a}$ & $9.63 \mathrm{~b}$ & $293.00 \mathrm{ab}$ \\
Teranil 45 DP & $72.50 \mathrm{ab}$ & $9.13 \mathrm{~b}$ & $332.67 \mathrm{ab}$ \\
Divind Star 036FS & $69.16 \mathrm{~b}$ & $7.18 \mathrm{~b}$ & $340.67 \mathrm{a}$ \\
Control & $55.00 \mathrm{c}$ & $39.26 \mathrm{a}$ & $193.00 \mathrm{~b}$ \\
LSD & 6.71 & 20.16 & 147.60 \\
\hline
\end{tabular}

Similar letter(s) in a column do not differ significantly at $1 \%$ level of probability

The interaction between metrological parameters and disease incidence was shown in Figure 1. It was noted that first disease incidence of this study was recorded in the month of December when average maximum temperature and relative humidity were $23.13^{\circ} \mathrm{C}$ and $61.66 \%$ respectively. The condition of soil was also dry and suitable for onset of the disease. The disease incidence increased with crop maturity and decrease of 
relative humidity. The maximum disease incidence of $39.26 \%$ was recorded near pod maturity in control plot when temperature and relative humidity were $32.17{ }^{\circ} \mathrm{C}$ and $48.41 \%$ respectively. The increase in disease incidence was rapid in control plot as compared with seed treated plots as shown in Figure 1.

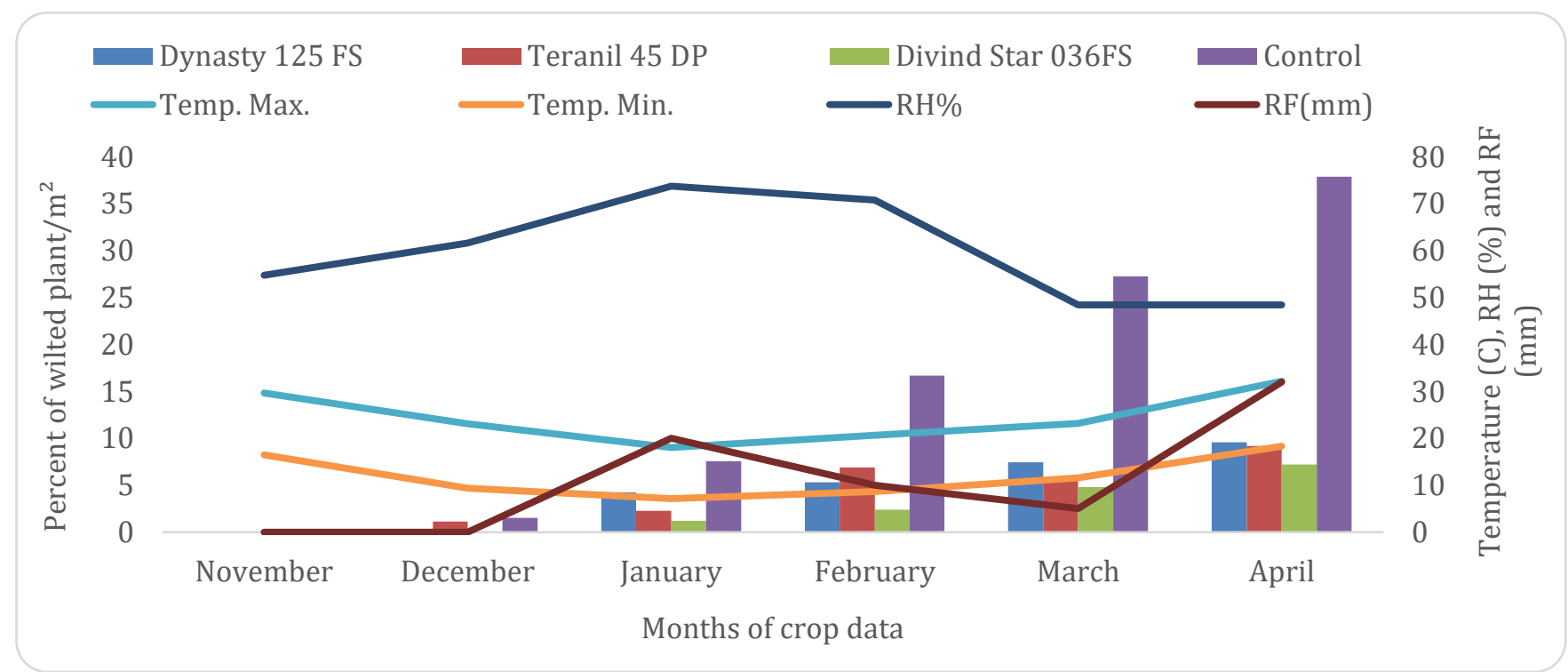

Figure 1. Incidence of gram wilt during different growth periods of crop season having seed treatment of different fungicides and effect of metrological parameters.

\section{DISCUSSION}

Gram wilt disease incidence showed appositive but nonsignificant correlation with the maximum and minimum temperature as shown in Table 2 . The same results were found for the incidence of wilt of pigeon pea crop (Reddy et al., 1990; Singh and Bhargava, 1981). It was also observed that the occurrence of wilt disease started when soil conditions were dry due to absence of rainfall as concluded in earlier studies (Chhetry and Ranjana, 2014; Gupta et al., 2003). The disease incidence was observed when maximum temperature was $23^{\circ} \mathrm{C}$ similar to the findings that wilt disease proliferate at $25^{\circ} \mathrm{C}$ (Gupta et al., 2003).

It is also noted that control of gram wilt disease is not possible through adopting signal management option. However, seed treatment is the most economical and best option in chemical control of this disease in gram crop of Thal area. The similar observations were mentioned in earlier studies regarding use of seed treatment option for seed borne diseases of pulses and gram (Gupta, 2006; Khalequzzaman, 2008; Rashid et al., 2000). The present study is proposing different techniques to control wilt complex because the minimum wilt incidence in this study was also about $7 \%$ which can be minimized by using other techniques (cultural + bio fungicides) as mentioned in earlier studies (Andrabi et al., 2011). Divind
Star has shown maximum reduction of wilt incidence in gram crop but its effect on germination rate was negative as compared with other fungicides as similar to the observations of Maitlo et al. (2014) stating that the higher concentration of some fungicides can effectively control pathogen but suppress plant growth. Mahmood et al. (2015) also presented Divind Star as an effective fungicide for controlling gram wilt through seed treatment. The similar results of seed treatment with fungicides were also reported by Chang et al. (2014). for suppressing the pathogens in faba beans. Subhani et al. (2011) examined different fungicides for control of gram wilt and found that drenching or seed treatment is effective way to suppress the disease as in our study proved that seed treatment is better option to use fungicides.

Conclusion: The results of this study proved that seed treatment of gram seeds at the time of sowing is helpful for controlling gram wilt caused during the rainy season in irrigated gram crop areas like Layyah District. Divind Star 036FS proved best fungicide for seed treatment to lower down the disease incidence while Dynasty 125 FS proved best for increasing the percent germination over control. Seed treatment of these fungicides can be helpful for controlling gram wilt.

Author contributions: All the authors planned and 
designed the studies, helped in conducting the trial, collection and analysis of data and writing the manuscript.

Conflict of interest: The authors declare no conflict of interest.

Acknowledgement: The authors are thankful to Pest Warning and Quality Control of Pesticides Wing of Agriculture Department, Government of Punjab for providing funds to conduct this study.

\section{REFERENCES}

Ahmad, M.A., 2010. Variability in Fusarium oxysporum f. sp. ciceri for chickpea wilt resistance in Pakistan, Department of Botany. Quaid-i-Azam University Islamabad, Pakistan.

Andrabi, M., Vaid, A., Razdan, V., 2011. Evaluation of different measures to control wilt causing pathogens in chickpea. Journal of Plant Protection Research 51, 55-59.

Auckland, A.K., Van-der-Maesen, L.J.G., 1980. Chickpea ICRISAT. Crop Science Society of America 667, 249259.

Ayub, N., Ahmad, Y., Akram, A., 2010. Identification of resistant sources in chickpea against Fusarium wilt. Pakistan Journal of Botany 42, 417-426.

Bakhsh, A., Iqbal S.M., Haq, I.K., 2007. Evolution of chickpea germplasm for wilt resistance. Pakistan Journal of Botany 39, 583-593.

Berani, N.K., Damor, M.P., Godhani, P.H., 2018. Impact of date of sowing on lepidopteran insect pest of black gram, Vigna mungo (L.) Hepper. Journal of Entomology and Zoology Studies 6, 24-26.

Bouslama, M., 1980. Chickpea improvement in Tunisia, International Workshop on Chickpea Improvement, International Crops Research Institute for the Semi-Arid Tropics (ICRISAT), Patancheru, India., pp. 277-280.

Chang, K.F., Conner, R.L., Hwang, S.F., Ahmed, H.U., McLaren, D.L., Gossen, B.D., Turnbull, G.D., 2014. Effects of seed treatments and inoculum density of Fusarium avenaceum and Rhizoctonia solani on seedling blight and root rot of faba bean. Canadian Journal of Plant Science 94, 693-700.

Chhetry, G.K.N., Ranjana, D.T., 2014. Wilt epidemiology of pigeonpea (Cajanus cajan (L.) Millsp.) in organic farming system. IOSR Journal of Agriculture and Veterinary Science 7, 1-6.

Dhar, V., Gurha, S.N., 1998. Integrated Management of Chickipea Diseases, in: Rajeev, K., Upadhyay, K.G.,
Mukerji, B.P., Dubey, O.P. (Eds.). APH Publishing Company New Delhi.(India).

FAO, 2014. Agricultural statistics of Pakistan. Ministary of Food and Agriculture Division Governament of Pakistan.

Gupta, A., 2006. Efficacy of bio-agents vs. fungicides on disease incidence in chickpea. Annals of Plant Protection Sciences 14, 496-497.

Gupta, S.B., Thakur, M.P., Tedia, K., Singh, A.K., Bachkaiya, K.K., Thakur, K., 2003. Studies on local isolates of Trichoderma viride and their relationship with wilt/root rot causing fungi of chickpea, Chickpea Research for the Millennium. International Chickpea Conference, Raipur, Chhattisgarh, India, pp. 184-191.

Haware, M.P., 1990. Fusarium wilt and other important diseases of chickpea in the Mediterranean area. Options Mediterraneenes, 61-64.

Haware, M.P., Nene, Y.L., Natarajan, M., 1996. Survival of Fusarium oxysporum f. sp. ciceri. in the soil in the abseebce of chickpea. Phytopathologia Mediterranea 35, 9-12.

Jalali, B.L., Chand, H., 1992. Chickpea wilt, in: Singh, U.S., Mukhopadhayay, A.N., Kumar, J., Chaube, H.S. (Eds.), Plant Diseases of International Importance. Volume I., Diseases of Cereals and Pulses. (Eds.): Prentice Hall Englewood Cliffs, NewJersey., pp. 492-444.

Khalequzzaman, K.M., 2008. Effect of seed treating fungicides and biofertilizers in the incidence of foot and root rot disease of lentil and chickpea. Annals of Bangladesh Agriculture 12, 39-44.

Khan, H.R., Iqbal, S.M., Haqqani, A.M., Khan, M.S.A., Malik, B.A., 1991. Thal-the home of chickpea in Pakistan. International Chickpea Newsletter 24, 7-10.

Nene, Y.L., 1985. Opportunities for research on diseases of pulse crops. Indian Phytopathology 38, 1-10.

Nene, Y.L., Reddy, M.V., 1987. Chickpea diseases and their control, in: Saxena, M.C., Singh, K.B. (Eds.), The Chickpea. $\mathrm{CAB}$ International Oxon, United Kingdom, pp. 233-270.

Pande, S., Rao, J.N., Sharma, M., 2007. Establishment of the chickpea wilt pathogen F.oxysporum f. sp. ciceris in the soil through seed transmission. Plant Pathology Journal 23, 3-6.

Pandey, G.K., Ahmad, S., Zacharia, S., 2018. Management of chick pea wilt caused by Fusarium oxysporum f. sp. ciceri. Journal of Entomology and Zoology 
Studies 6, 618-624.

Rashid, M.H., Khalequzzaman, K.M., Khan, M.A.A., 2000. Efficacy of different fungicides in controlling root rot of French bean caused by Rhizoctonia solani Kuhn. Bangladesh Horticulture 28, 9-11.

Reddy, M.V., Sharma, S.B., Nene, Y.L., 1990. Pigeonpea disease management, in: Nene, Y.L., Hall, S.D., Sheila, V.K. (Eds.), The Pigeonpea. CAB International, Wallingford, Oxon, U.K., pp. 303-307.

Shafiq, M., Akhtar, M.S., Naveed, M., Khan, A.A., Muhammad, N., 2011. Punjab-2008; A high yielding and wilt resistant chickpea variety for irrigated and rainfed areas. Journal of Agricultural Research 49,
19-26.

Singh, A.P., Bhargava, S.N., 1981. Survival studies on three species of Fusarium causing wilt of pigeonpea. Phytopathologische Zetschrift 100, 300-311.

Subhani, M.N., Sahi, S.T., Hussain, S., Ali, A., Iqbal, J., Hameed, K., 2011. Evaluation of various fungicides for the control of gram wilt caused by Fusarium oxysporium f. sp. ciceris. African Journal of Agricultural Research 6, 4555-4559.

Trapero-Casas, A., Jiménez-Díaz, R.M., 1985. Fungal wilt and root rot diseases of chickpea in southern Spain. Phytopathology 75, 1146-1151. 